\title{
Variability in Distribution and Virulence Phenotypes of Heterodera glycines in Missouri During 2005
}

\author{
Melissa G. Mitchum, Division of Plant Sciences and Bond Life Sciences Center, University of Missouri-Columbia, \\ Columbia 65211; J. Allen Wrather, Division of Plant Sciences, University of Missouri-Delta Center, Portageville \\ 63873; Robert D. Heinz, Division of Plant Sciences and Bond Life Sciences Center, University of Missouri- \\ Columbia; J. Grover Shannon, Division of Plant Sciences, University of Missouri-Delta Center; and Gene Danekas, \\ United States Department of Agriculture, Agriculture Statistics Service, Columbia, MO 65205
}

\begin{abstract}
Mitchum, M. G., Wrather, J. A., Heinz, R. D., Shannon, J. G., and Danekas, G. 2007. Variability in distribution and virulence phenotypes of Heterodera glycines in Missouri during 2005. Plant Dis. 91:1473-1476.

The soybean cyst nematode, Heterodera glycines, is a serious economic threat to soybean producers in Missouri. Periodic monitoring for the presence, population densities, and virulence phenotypes of $H$. glycines is essential for determining crop losses and devising management strategies implementing the use of resistant cultivars. A survey using area-frame sampling was conducted to determine the distribution and virulence phenotypes of $H$. glycines in Missouri during 2005. Two samples from each of 125 fields representing eight geographical regions of Missouri were collected; 243 samples were processed for extraction of cysts and eggs. In all, $49 \%$ of samples had detectable cyst nematode populations, which ranged from 138 to 85,250 eggs per $250 \mathrm{~cm}^{3}$ of soil. Race and $H$. glycines type tests were conducted on populations from 45 samples. Nearly $80 \%$ of the populations that were tested, irrespective of the region, were virulent on the indicator line plant introduction (PI) 88788, which is the source of resistance for most $\mathrm{H}$. glycines-resistant cultivars. More than $70 \%$ of populations could reproduce on the indicator lines PI 88788, PI 209332, and PI 548316 (Cloud), indicating that soybean cultivars with resistance derived from these sources need to be carefully monitored and used only in rotation with nonhost crops and soybean cultivars with resistance from other sources. Approximately one-third of the populations, primarily in the southern regions of Missouri, could reproduce on PI 548402 (Peking), another common source of resistance. Fewer than $10 \%$ of the populations could reproduce on PI 90763, PI 437654, PI 89772, or PI 438489B, suggesting that these sources of resistance should be used in soybean breeding programs to develop H. glycinesresistant soybean cultivars.
\end{abstract}

Additional keywords: Glycine max, HG types

The soybean cyst nematode ( $\mathrm{SCN})$, Heterodera glycines Ichinohe, continues to be a major limiting factor in soybean (Glycine max (L.) Merr.) production. Yield suppression attributed to $H$. glycines resulted in an estimated $\$ 750$ million in losses to U.S. soybean producers annually from 2003 to 2005 (10). Primary means of management include resistant cultivars and rotation with nonhost crops. However, high levels of genetic diversity in field populations of $H$. glycines contribute to their ability to quickly adapt to resistant cultivars, reducing their effectiveness.

Corresponding author: J. A. Wrather

E-mail: wratherj@missouri.edu

* The $\boldsymbol{e}$-Xtra logo stands for "electronic extra" and indicates that a supplemental table not included in the print edition is available online.

Accepted for publication 18 June 2007.

doi:10.1094/PDIS-91-11-1473

(C) 2007 The American Phytopathological Society
In addition to determining frequency and population densities of $H$. glycines, knowledge of the $H$. glycines (HG) type (5) distribution is essential for soybean breeders, agronomists, and nematologists to prioritize research and establish management recommendations for growers. In the past, $H$. glycines field population variability has been assessed by determining the frequency of races (8). Each race is an average of population phenotype defined by its ability (female index $[\mathrm{FI}] \geq 10=+$ ) or lack thereof $(\mathrm{FI} \leq 10=-)$ to develop on a set of four soybean differentials compared with a susceptible check. In 2002, a new classification scheme referred to as the HG type test was proposed to replace the race scheme (5). The HG type test is based on the same methodology as that of the race scheme, but it includes seven plant introductions (PIs) known to have been used in developing $H$. glycines-resistant germplasm. The population is named according to the number associated with the soybean PI on which it is virulent $(\mathrm{FI} \geq 10)$.

Survey data collected by area-frame sampling $(2,7)$ of the soybean-producing regions of a state can provide valuable and unbiased information pertaining to the level of infestation, distribution, and virulence phenotypes of $H$. glycines. Prior surveys have confirmed that $H$. glycines infests a large percentage of soybean fields in Missouri $(3,6,7)$; however, a comprehensive survey of frequency and virulence phenotypes of $H$. glycines has not been conducted in Missouri since 1998. The objective of this study was to determine the variability in distribution and density of $H$. glycines, as well as the diversity of virulence phenotypes of $H$. glycines, in Missouri during 2005, and to compare these data with results of a survey conducted in 1998 (7).

\section{MATERIALS AND METHODS}

The United States Department of Agriculture National Agriculture Statistics Service area-frame probability sampling design (2) was used to select fields in Missouri planted to soybean in 2005. Sampling frequency in this design was weighted by production acreage. Eight geographic regions of Missouri (Fig. 1) were sampled. No samples were collected from the south-central (Ozark) region because it is an area of low frequency of soybean fields. During October 2005, 125 fields were sampled. A soil sample was collected from each of two 0.25-ha areas separated by at least $100 \mathrm{~m}$ within each field (4). Samples from 7 fields were lost, for a total of 243 samples analyzed. Each sample was a composite of 20 soil cores (15 $\mathrm{cm}$ deep by $2.0 \mathrm{~cm}$ in diameter) (1). Soil samples were sealed in plastic bags and shipped by 2-day express to the University of Missouri Extension Nematology Laboratory for analysis. Samples were stored in a cold room at between 4 and $10^{\circ} \mathrm{C}$ until they were processed. Soil samples were air dried and thoroughly mixed, and a $100-\mathrm{cm}^{3}$ subsample was used to extract $H$. glycines eggs by elutriation and mechanical cyst crushing as described previously (7). Population densities are reported in eggs $/ 250 \mathrm{~cm}^{3}$ of soil.

For race and HG type testing, samples were selected from fields where at least one sample contained $>1,000$ eggs $/ 250$ $\mathrm{cm}^{3}$ of soil (except for one additional sample from Gentry County). If both samples from the same field contained $>1,000$ 
eggs $/ 250 \mathrm{~cm}^{3}$ of soil, one was arbitrarily chosen for race and HG type testing. All samples with $<10,000 \mathrm{eggs} / 250 \mathrm{~cm}^{3}$ of soil were increased one to two generations on susceptible soybean cv. Lee 74 to rear sufficient numbers of eggs for race and HG type testing. Five samples did not increase well during this process (one each from Chariton, Lewis, Pike, Lincoln, and New Madrid Counties) and could not be used

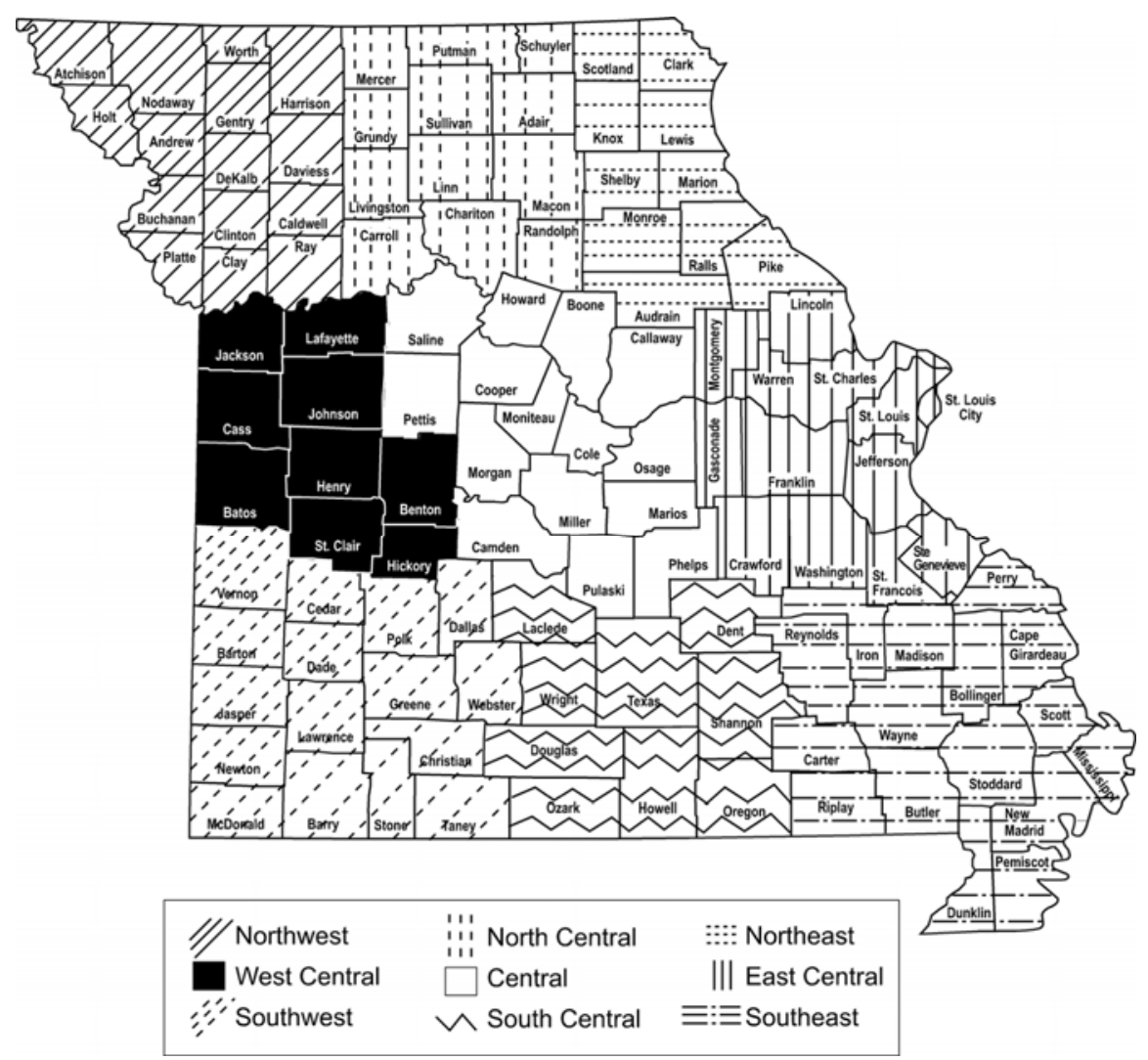

Fig. 1. Counties in Missouri divided into geographical regions for sampling of Heterodera glycines in soybean fields in 2005 .

Table 1. Frequency and population densities of Heterodera glycines in Missouri during 2005 according to regions illustrated in Figure 1

\begin{tabular}{lccccc}
\hline Region & Soil samples $^{\mathbf{a}}$ & No. positive $^{\mathbf{b}}$ & Positive (\%) $^{\mathbf{c}}$ & No. tested $^{\mathbf{d}}$ & No. of eggs $^{\mathbf{e}}$ \\
\hline Northwest & 38 & 20 & 53 & 10 & 60,300 \\
North-central & 40 & 15 & 38 & 4 & 22,275 \\
Northeast & 46 & 32 & 70 & 12 & 21,175 \\
West-central & 21 & 7 & 33 & 3 & 85,250 \\
Central & 20 & 6 & 30 & 4 & 13,750 \\
East-central & 12 & 7 & 58 & 2 & 20,625 \\
Southwest & 8 & 5 & 63 & 2 & 19,364 \\
Southeast & 58 & 27 & 47 & 8 & 26,400 \\
Total & 243 & 119 & 49 & 45 & $33,642^{\text {f }}$
\end{tabular}

a Number of soil samples.

${ }^{\mathrm{b}}$ Number of samples positive for $H$. glycines.

${ }^{c}$ Percent of samples positive for $H$. glycines.

${ }^{\mathrm{d}}$ Number of samples tested for race and HG type.

${ }^{\mathrm{e}}$ Maximum number of $\mathrm{H}$. glycines eggs $/ 250 \mathrm{~cm}^{3}$ of soil.

${ }^{\mathrm{f}}$ Average of samples.

Table 2. Distribution of Heterodera glycines races and HG types in 2005 by region of Missouri

\begin{tabular}{lll}
\hline Region & Races & \multicolumn{1}{c}{ HG type } \\
\hline Northwest & 1,3 & $2.5 .7,5.7,7$ \\
North-central & 1,4 & $2.7,2.5 .7,1.2 .3 .5 .6 .7 .8$ \\
Northeast & $1,2,3,5$ & $2.7,2.5 .7,7,1.2 .5 .7$ \\
West-central & 1 & 2.5 .7 \\
Central & 1,3 & $2.5 .7,7$ \\
East-central & 3,5 & $2.5 .7,7$ \\
Southwest & 2 & $1.2 .5 .6 .7,1.2 .5 .7$ \\
Southeast & 2,4 & $1.2 .5 .7,1.2 .3 .5 .6 .7,1.2 .3 .5 .6 .7 .8$ \\
\hline
\end{tabular}

for testing. Samples from fields where $H$. glycines was found in only one sample, and where this sample had $<1,000$ eggs $/ 250 \mathrm{~cm}^{3}$ of soil, were not used in race and HG type testing. Thus, race and HG type tests were conducted on populations from 45 samples.

Populations were reared on susceptible soybean for 30 to 60 days in a water bath at $27^{\circ} \mathrm{C}$, plant root systems were removed from pots, cysts were collected, and eggs were extracted for use in race (8) and $\mathrm{HG}$ type (5) tests. The resistant PI 438489B (11) was added to the set of differentials used in the HG Type test. FIs were calculated for each soybean line as follows: $\mathrm{FI}=$ (mean number of females on test soybean line per mean number of females on Lee) $\times 100$.

\section{RESULTS}

In this study, 243 soil samples were processed successfully for egg counts. In all, $119(49 \%)$ of the samples had detectable populations of eggs from cysts similar in size to $H$. glycines. The greatest population density detected in a Missouri field sample was 85,250 eggs/250 $\mathrm{cm}^{3}$ (Table $1)$. The population density was $\geq 500$ eggs $/ 250 \mathrm{~cm}^{3}$ in $37 \%$ of samples.

Of the 119 samples that had detectable levels of $H$. glycines, 45 were used for race and HG type testing. The distribution of $H$. glycines races and HG types varied among regions of Missouri during 2005 (Table 2). Races 1, 2, and 3 were most common and accounted for $44.4,22.2$, and $22.2 \%$ of the populations sampled, respectively (Table 3 ). Races 1 and 3 were present in most regions of the state except the southwest and southeast (Table 2). Race 2 was present in the northeast, southeast, and southwest regions of the state (Table 2). Races 4 or 5 , or both, were detected in the northcentral, northeast, east-central, and southeast regions of the state (Table 2) and represented approximately $11 \%$ of populations sampled (Table 3 ). HG type tests also were conducted on the 45 samples. HG types $2.5 .7,1.2 .5 .7$, and 7 were the most predominant, accounting for 40,20 , and $17.8 \%$ of the populations sampled, respectively (Table 3).

Most of the $H$. glycines populations tested during 2005 were able to parasitize PI 88788, PI 209332, and PI 548316, but few were able to parasitize PI 90763, PI 437654, PI 89772, and PI 438489B (Table 4). PI 438489B was added to the differential set used to evaluate populations and only $4 \%$ of populations developed on this line (Table 4). None of the populations tested developed on PI 437654.

The percentage of $H$. glycines populations collected in 2005 developing on soybean lines with resistance to $H$. glycines varied by region of Missouri (Table 4). Populations that could reproduce on PI 88788, PI 209332, and PI 548316 (Cloud) were identified in all regions of Missouri 
sampled. The majority of populations that could reproduce on PI 548402 (Peking) were located in the southeast and southwest regions of the state. The small percentage of populations that could reproduce on PI 90763, PI 89772, and PI 438489B were located in the north-central, southeast, or southwest regions of the state (Table 4).

\section{DISCUSSION}

Based on the 2005 survey, detectable levels of $H$. glycines were found in nearly $50 \%$ of soil samples collected from Missouri soybean fields regardless of region within the state. Niblack et al. (7) reported that $63 \%$ of samples collected using areaframe sampling from Missouri soybean fields in 1998 contained detectable levels of $H$. glycines. The reasons for differences in frequency of $H$. glycines in samples collected during 1998 and 2005 are not understood and we cannot exclude the possibility of random variation. However, the decline in frequency of $H$. glycines in samples from 1998 to 2005 in most regions of Missouri could be due to increased awareness of $H$. glycines among soybean producers and subsequent increased use of crop rotation and planting of $H$. glycines-resistant cultivars. The

Table 3. Percentage of Heterodera glycines populations tested during 2005 designated as a particular H. glycines (HG) type or race ${ }^{\mathrm{a}}$

\begin{tabular}{lc}
\hline HG type or race & Population $(\boldsymbol{\%})$ \\
\hline HG type & \\
1.2 .3 .5 .6 .7 .8 & 4.4 \\
1.2 .3 .5 .6 .7 & 2.2 \\
1.2 .5 .6 .7 & 2.2 \\
1.2 .5 .7 & 20 \\
2.5 .7 & 40 \\
2.7 & 8.9 \\
5.7 & 4.4 \\
7 & 17.8 \\
Race & \\
1 & 44.4 \\
2 & 22.2 \\
3 & 22.2 \\
4 & 6.7 \\
5 & 4.4 \\
\hline
\end{tabular}

${ }^{a}$ Forty-five samples were tested.
United States Department of Agriculture does not collect data concerning the rotation or tillage practices of the farmers participating in the survey, and farmer identities remain anonymous; thus, these data are unavailable.

The percentage of samples with $\geq 500$ eggs $/ 250 \mathrm{~cm}^{3}$ was $37 \%$ in 2005 compared with $60 \%$ of infested samples with $\geq 500$ eggs/250 $\mathrm{cm}^{3}$ in 1998 (7). The damage threshold used by the Extension Nematology Laboratory in Missouri is 500 eggs/250 $\mathrm{cm}^{3}$ of soil (R. Heinz, unpublished), representing the average population density at which yields may be significantly $(P \leq 0.05)$ reduced $(7)$. Rotation with nonhost crops and planting resistant cultivars to limit soybean yield suppression due to $H$. glycines is recommended when sample populations exceed this level.

Knowledge of the distribution of $H$. glycines virulence phenotypes is essential for soybean breeders, agronomists, and nematologists to establish management recommendations for growers and to prioritize future research. The results of this survey indicate that the virulence phenotypes of $H$. glycines in Missouri have shifted between 1998 and 2005. In 1998, in order of frequency, races 3,1 , and 2 were most common and individually accounted for $32.8,29.5$, and $23.5 \%$, respectively, of the populations sampled. In 2005, races 1, 2, and 3 were most common and accounted for $44.4,22.2$, and $22.2 \%$ of the populations sampled, respectively. Race 1 can reproduce on PI 88788 whereas race 3 cannot. The percentage of populations that developed on PI 88788 was higher in 2005 (78\%) compared with 1998 (58\%) (7), but the percentage developing on PI 548402, PI 90763, and PI 437654 remained similar in both years.

The increase in the percentage of Missouri populations of $H$. glycines developing on PI 88788 from 1998 to 2005 may be due to the increased planting of soybean cultivars with resistance to $H$. glycines from this source and the subsequent development of virulent populations. Most farmers in Missouri plant commercial soybean cultivars, and information about the acres planted to each and the percentage of acres planted to cultivars with SCN resistance genes is proprietary. There were 377 soybean cultivars included in the 2005 University of Missouri Variety Testing Program, and the companies that released these claimed that four of them $(1.1 \%)$ had SCN resistance from PI 437654 or Hartwig, one $(0.26 \%)$ had SCN resistance from Peking, one $(0.26 \%)$ had SCN resistance from Cyst X, and 269 (71\%) had SCN resistance from PI 88788. All others were susceptible to SCN (9). This suggests that a majority of SCN-resistant cultivars planted in Missouri fields have SCN resistance genes from PI 88788. Our data suggest that cultivars with resistance from PI 88788 in Missouri need to be carefully monitored and used only in rotation with nonhost crops and soybean with resistance from other germplasm sources (e.g., PI 437654, PI 90763, PI 89772, and PI 438489B).

Based on HG type testing, 73, 9, and $100 \%$ of the populations surveyed in 2005 were able to reproduce on PI 209332, PI 89772, and PI 548316, respectively. Similar to PI 88788, lines PI 209332 and PI 548316 are not good sources of resistance for developing $H$. glycines-resistant soybean cultivars in Missouri.

Cultivars with resistance from PI 548402 (Peking) will resist most $H$. glycines populations in central and north Missouri; only three populations of 16 tested from these areas had an FI $>10$. All of the $H$. glycines populations from south Missouri were able to reproduce on this line, suggesting that cultivars with only this source of resistance will not be useful in the southeast and southwest regions of the state.

None of the $H$. glycines populations collected from Missouri during 2005 and tested for HG type produced a cyst on PI 437654. Twenty populations collected from Missouri during 1998 were able to produce one or more females on PI 437654, but only three had a FI > 10 (7). The reason for this difference between populations collected during 1998 and 2005 is not known; however, it is possible

Table 4. Percentage of Heterodera glycines populations collected during 2005 from regions of Missouri developing on soybean plant introduction (PI) lines with resistance to $H$. glycines

\begin{tabular}{|c|c|c|c|c|c|c|c|c|c|}
\hline \multirow[b]{2}{*}{ Soybean line } & \multicolumn{8}{|c|}{ Region $^{a}$} & \multirow[b]{2}{*}{ State } \\
\hline & NW & $\mathrm{NC}$ & NE & WC & C & EC & SW & SE & \\
\hline Pickett & 0 & 25 & 25 & 0 & 0 & 50 & 100 & 100 & 33 \\
\hline PI 548402(Peking) & 0 & 25 & 17 & 0 & 0 & 0 & 100 & 100 & 29 \\
\hline PI 88788 & 30 & 100 & 92 & 100 & 75 & 50 & 100 & 100 & 78 \\
\hline PI 90763 & 0 & 25 & 0 & 0 & 0 & 0 & 0 & 25 & 7 \\
\hline PI 437654 & 0 & 0 & 0 & 0 & 0 & 0 & 0 & 0 & 0 \\
\hline PI 209332 & 50 & 50 & 75 & 100 & 75 & 50 & 100 & 100 & 73 \\
\hline PI 89772 & 0 & 25 & 0 & 0 & 0 & 0 & 50 & 25 & 9 \\
\hline PI 548316 (Cloud) & 100 & 100 & 100 & 100 & 100 & 100 & 100 & 100 & 100 \\
\hline PI 438489B & 0 & 25 & 0 & 0 & 0 & 0 & 0 & 13 & 4 \\
\hline Total (tested) ${ }^{\mathrm{b}}$ & $20(10)$ & $15(4)$ & $32(12)$ & $7(3)$ & $6(4)$ & $7(2)$ & $5(2)$ & $27(8)$ & $119(45)$ \\
\hline
\end{tabular}

${ }^{\mathrm{a}} \mathrm{NW}=$ northwest, $\mathrm{NC}=$ north-central, $\mathrm{NE}=$ northeast. $\mathrm{WC}=$ west-central, $\mathrm{C}=$ central, $\mathrm{EC}=$ east-central, $\mathrm{SW}=$ southwest, and $\mathrm{SE}=$ southeast.

${ }^{\mathrm{b}}$ Total number of $H$. glycines-positive samples; number in parenthesis = number of $H$. glycines-positive samples tested. 
that some of the populations collected in 2005 that were not tested for HG type may reproduce on PI 437654. In addition, the sampling design used in 1998 and 2005 did not result in the same fields sampled each year. Thus, populations that can develop on this line may still be in a few Missouri fields or they may not be detectable. Based on the 2005 survey, PI 437654 remains an excellent source of broad-based resistance to $H$. glycines in Missouri.

Similarly, few populations from Missouri collected during 1998 and 2005 reproduced on PI 90763, and few of the populations collected during 2005 reproduced on PI 89772 and PI 438489B. PI $438489 \mathrm{~B}$ is reported to have resistance to a broad spectrum of $H$. glycines races (11). Soybean cultivars with resistance derived from PI 438489B have not yet been deployed; however, our results suggest that H. glycines populations that can reproduce on PI 438489B do exist at a low frequency in Missouri.

Soybean breeders should focus on incorporating resistance from PI 437654, PI 90763, PI 89772, or PI 438489B into cultivars adapted to conditions throughout Missouri. Cultivars from these or other sources with resistance to predominant SCN HG types in Missouri would broaden the genetic base of $H$. glycines resistance in commercially available soybean cultivars and provide more rotation options for growers.

The differences in frequency and virulence phenotypes of $H$. glycines by region of Missouri and between 1998 and 2005 show that populations of this nematode certainly are not static. Therefore, periodic monitoring of HG type population density, distribution, and virulence phenotypes is highly recommended.

\section{ACKNOWLEDGMENTS}

This work was supported, in part, by the Missouri Agriculture Experiment Station and the United States Department of Agriculture (Special Grant 2004-34113-14489). We thank J. Elrod for her help in this project and J. Goellner for artistic assistance with Figure 1.

\section{LITERATURE CITED}

1. Barker, K. R., Townshend, J. L., Michell, R. E., and Norton, D. C. 1978. Determining nematode population responses to control agents. Pages 114-127 in: Methods of Evaluating Plant Fungicides, Nematicides, and Bactericides. E. I. Zehr, G. W. Bird, K. D. Fisher, and K. D. Hickey, eds. The American Phytopathological Society, St. Paul, MN.

2. Cotler, J., and Nealon, J. 1987. Area Frame Design for Agriculture Surveys. National Agriculture Statistics Service, United States Department of Agriculture.

3. Heinz, R., Sweets, L. E., and Mitchum, M. G. 2006. SCN-resistant soybeans offer a false sense of security to producers. Univ. Mo. Inte- grated Pest Crop Manage. Newsl. Online. Volume 16, No. 1. Available at http://ipm.missouri edu/ipcm/archives/v16n1/ipmltr5.htm.

4. Neher, D. A., and Campbell, C.L. 1996. Sampling for regional monitoring of nematode communities in agricultural soils. J. Nematol. 28:196-208.

5. Niblack, T. L., Arelli, P. R., Noel, G. R., Opperman, C. H., Orf, J. H., Schmitt, D. P., Shannon, J. G., and Tylka, G. L. 2002. A revised classification scheme for genetically diverse populations of Heterodera glycines. J. Nematol. 34:279-288.

6. Niblack, T. L., Heinz, R. D., Smith, G. S., and Donald, P. A. 1993. Distribution, density, and diversity of Heterodera glycines in Missouri. J. Nematol. 25(4S):880-886.

7. Niblack, T. L., Wrather, J. A., Heinz, R. D. and Donald, P. A. 2003. Distribution and virulence phenotypes of Heterodera glycines in Missouri. Plant Dis. 87:929-932.

8. Riggs, R. D., and Schmitt, D. P. 1988. Complete characterization of the race scheme for Heterodera glycines. J. Nematol. 20:392395.

9. Wiebold, W. J., Mason, H. L, Knerr, D., Hasty, R. W., Belt, T., Adams, E. G., Schwab, D. M. Smothers, S. L., and Burdick, B. 2005. Soybean 2005 crop performance. Univ. Mo. Columbia Agric. Exp. Stn. Spec. Rep. 562.

10. Wrather, J. A., and Koenning, S. R. 2006 Estimates of disease effects on soybean yields in the United States 2003 to 2005. J. Nematol. 38:173-180.

11. Yue, P., Arelli, P. R., and Sleper, D. A. 2001. Molecular characterization of resistance to Heterodera glycines in soybean PI 438489B. Theor. Appl. Genet. 102:921-928. 